\title{
Antioxidant and antimicrobial activity of Ficus sycomorus fruit and leaf extracts
}

\author{
Melis SUMENGEN OZDENEFE $^{1}$ (D), Feryal TANOGLU ${ }^{2}$ (D), Kaya SUER ${ }^{3}$ (D), Emrah GULER ${ }^{4}$ (i), Hatice Aysun MERCIMEK TAKCI ${ }^{5}$ \\ ${ }^{1}$ Department of Biomedical Engineering, Near East University, Nicosia, North Cyprus via Mersin 10 Turkey. \\ ${ }^{2}$ Department of Food Engineering, Near East University, Nicosia, North Cyprus via Mersin 10 Turkey. \\ ${ }^{3}$ Department of Infectious Diseases and Clinical Microbiology, Near East University, Nicosia, North Cyprus via Mersin 10 Turkey. \\ ${ }^{4}$ Department of Microbiology and Clinical Microbiology, Near East University, Nicosia, North Cyprus via Mersin 10 Turkey. \\ ${ }^{5}$ Department of Molecular Biology and Genetics, Kilis 7 Aralik University, Kilis, Turkey.
}

Corresponding Author: Melis SUMENGEN OZDENEFE

E-mail: melissumengen@hotmail.com / melis.ozdenefe@neu.edu.tr

Submitted: 08.06.2020 Accepted: 10.08.2020

\begin{abstract}
Objective: The aim of this study was to determine the antioxidant and antimicrobial activity of Ficus sycomorus fruit and leaf extracts obtained from the Turkish Republic of Northern Cyprus.

Materials and Methods: Fruits and leaves of F. sycomorus were collected from the Kyrenia region of Northern Cyprus in July 2018. The leaf and fruit samples were extracted with the distilled water, methanol, ethanol, acetone and chloroform solvents (1:10 [w/v]). After evaporation, samples were suspended in methanol at the final concentration of $100 \mathrm{mg} / \mathrm{mL}$. The antimicrobial activity of the leaf and fruit extracts was evaluated using the Kirby-Bauer Disk Diffusion Method. Total phenolic content (TPC) and total flavonoid content (TFC) of the extracts were determined using the methods reported by Stankovic in 2011 and Sharm and Vig in 2013. Antioxidant activity of samples was tested using free radical scavenger method.

Results: The leaf extracts of F. sycomorus was active. The inhibition zone diameters ranged from $1.8 \mathrm{~mm}$ to $13.00 \mathrm{~mm}$. Fruit extracts and methanol controls showed no inhibitory effect on strains. However, bacteriostatic activity against Enterococcus faecalis was observed in fruit-water extract. The highest antimicrobial activity was shown against Staphylococcus aureus $(13 \mathrm{~mm})$ for ethanolic extracts at $100 \mathrm{mg} / \mathrm{mL}$ concentration. Minimal inhibition concentration (MIC) for ethanolic extract was observed starting at 25 $\mathrm{mg} / \mathrm{mL}$ concentration against $S$. aureus. Although, no antimicrobial activiy was observed in fruit extracts, the highest 2,2-diphenyl 1-picrylhydrazyl (DPPH) activiy and phytochemical content were recorded in fruit extracts.

Conclusion: These results demonstrate that leaf extracts of F. sycomorus can be used as a curative agent for the treatment of S. aureus and fungal infections and may be effective against pathogenic microorganisms that are resistant to antibiotics. Antioxidant content of fruit and leaf extracts can be effective against the negative effects of free radicals.

Keywords: Antioxidant activity, F. sycomorus, S. aureus
\end{abstract}

\section{INTRODUCTION}

Ficus sycomorus belongs to the Moraceae, which is a family of flowering plants, containing about forty genera and more than thousand species. This family is the best commonly found in tropical and subtropical areas and is often referred to as the mulberry family or the fig family [1]. The plant is indigenous to African countries and mostly grows well in tropical countries like Oman. It also grows in the Arabian Peninsula and in Lebanon. It is also found in Cyprus, Madagascar, Israel and Egypt. The plant grows to a height of about 10 to $20 \mathrm{~m}$. The branches of the plant begin from the lower part of the body and form shapes like umbrellas. The F. sycomorus leaves are dark green, yellowveined, heart-shaped and about 10 to $14 \mathrm{~cm}$ long. The diameter

of the fruits is about 2 to $3 \mathrm{~cm}$ and round. The fruits are green when they are raw, and they become yellow or red when they ripen [2]. In Northern Cyprus, the F. sycomorus fruit is known as 'Cümbez' 'Pharaoh fruit' among the people. The tree of cümbez is known to give fruit seven times a year. When the tree gives fruit, the fruit is scratched with a knife and the fruit is mature. Scratched fruits ripen after about 7-10 days and become ready to be consumed. The most well-known F. sycomorus plant in Northern Cyprus is located in the courtyard of the Lala Mustafa Paşa Mosque in Famagusta. The mosque was originally built as the Cathedral of Saint Nicholas. It is estimated that the tree was erected in 1298 when the construction of the cathedral began.

How to cite this article: Sumengen Ozdenefe M, Tanoglu F, Suer K, Guler E, Mercimek Takci HA. Antioxidant and antimicrobial activity of Ficus sycomorus fruit and leaf extracts. Marmara Med J 2020;33(3): 133-140, doi: 10.5472/marumj.816301 
The height of the tree is 15 meters and the estimated age is 715 . The body of the tree is surrounded by smaller branches growing from the main body. The body is divided into 7 branches after 2.70 meters. Each branch around the main body is said to have coincided with a century. It is the oldest and most vivid tree in Cyprus. The fact that this tree is the oldest tree in the history of the all island and witnessed many events from the past to the present make the historical Cümbez tree in this region culturally important $[3,4]$.

Extracts of fruit, leaf, root and stem bark of the plant are used to treat various ailments such as cough, diarrhea, skin infections, jaundice, snake bites, chest diseases, cold, dysentery, stomach disorders, lactation disorders, liver disease, epilepsy, tuberculosis, helminthiasis, infertility, and diabetes mellitus [5, $6]$.

Constantly developing technology, environmental pollution, contaminated waters, radiation, heavy metals, pesticides and oxygen metabolism in living cells cause the formation of free radicals in the human body [7]. Free radicals are known to cause many diseases, particularly cancer. Antioxidants protect our body against all damages caused by free radicals that threaten human health. The importance of foods containing antioxidants should be known and consumed in order to prevent the spread of cancer disease in Cyprus and all over the World. Another important problem is the resistance of bacteria to antibiotics. Nowadays, all around the world, exploratory work is going on to find effective solution against drug resistant bacteria [8]. The discovery of new antimicrobials through plants provides new approaches and benefits for minimizing antibiotic resistance. In many studies, it has been mentioned that Ficus species have potential antibacterial activity [9].

The facts that this important Cypriot plant has a value to the culture it belongs to, and that it is rare and not widely known and that there is no study that has been conducted on it in North Cyprus or in Turkey make this study worthwhile and valuable.

This study aimed to screen phytochemical properties and pharmacological activities of leaf and fruit extracts of $F$. sycomorus. The leaf and fruit extracts of the plant were prepared for the analysis using acetone, ethanol, pure water and methanol solvents. The minimum inhibitory concentration (MIC) regarding the antimicrobial activity of these medicinal plants was also examined.

\section{MATERIALS and METHODS}

\section{Chemicals, Culture Media and Antibiotics}

Ethanol, methanol, chloroform, acetone, 2,2-diphenyl-1picrylhydrazyl $(\mathrm{DPPH})$, sodium nitrite $\left(\mathrm{NaNO}_{2}\right)$ and sodium hydroxide $(\mathrm{NaOH})$ were purchased from Sigma-Aldrich, (Germany). Mueller Hinton Agar Butylated hydroxytoluene (BHT), Folin-Ciocalteu reagent, sodium bicarbonate $\left(\mathrm{NaHCO}_{3}\right)$ and gallic acid standard were purchased from Merck KgaA, (Germany). Aluminum chloride hexahydrate $\left(\mathrm{AlCl}_{3} \mathrm{H}_{12} \mathrm{O}_{6}\right)$, Phoenix ID Broth and Nystatin (Oxoid, 100 units) were purchased from ACROS, BD Phoenix and Oxoid (United
Kingdom). Blank antimicrobial discs, tetracycline (Bioanalyse Limited, $30 \mu \mathrm{g}$ ), ciprofloxacin (Bioanalyse Limited, $5 \mu \mathrm{g}$ ) and teicoplanin were purchased from (Bioanalyse Limited, $30 \mu \mathrm{g}$ ) Bioanalyse Limited, (Turkey).

\section{Collection and Preparation of Plant Material}

Fruits and leaves of F. sycomorus were collected from the Kyrenia region of Northern Cyprus in July 2018. The collected fruit and leaves were washed by distilled water to remove dust and soil and then dried. The washed fruits were cut into thin slices with a knife and dried in a food dehydrator machine and the washed leaves were dried at room temperature. The dried leaves and fruits were grounded with an electric mixer and stored in $a+4^{\circ} \mathrm{C}$ refrigerator until the day of use in the laboratory.

\section{Preparation and Extraction of Leaf and Fruit Extracts}

The leaf and fruit samples were extracted with the distilled water, methanol, ethanol, acetone and chloroform solvents $(1: 10[\mathrm{w} / \mathrm{v}])$ in the shaker for 72 hours at room temperature. Solvents, after being filtered by Wattman No. 4 paper (Camlab, $\mathrm{UK}$ ), were evaporated and then samples were suspended in methanol at the $100 \mathrm{mg} \mathrm{mL}^{-1}$ final concentration. The extracts were kept refrigerated at $+4^{\circ} \mathrm{C}$ for phytochemical analysis for the antioxidant, and antimicrobial activity.

\section{Antimicrobial Test}

The antimicrobial activity of the leaf and fruit extracts were evaluated by the Kirby-Bauer Disk Diffusion Method [10]. A total of 1 fungal and 7 bacteria species (Escherichia coli, Enterobacter cloacae, Klebsiella spp., Bacillus subtilis, Enterococcus faecalis, Staphylococcus aureus, Staphylococcus epidermidis and Candida albicans) were used for the antimicrobial test. The antibacterial activity was performed on Mueller Hinton Agar. $10 \mu \mathrm{L}$ of the microbial suspension was taken with a pipette and transferred to the center of Mueller Hinton agar and then spreaded homogeneously on the surface with a wooden cotton applicator stick. The sterile antimicrobial blank discs impregnated with 20 $\mu \mathrm{l}$ of the extracts were strategically placed away from each other. Methanol solvent and standard antibiotics were used as negative and positive controls, respectively. Tetracycline for B. subtilis, $S$. aureus and S. epidermidis; Ciprofloxacin for E. coli, E. cloacae and Klebsiella spp.; Nystatin for C. albicans and Teicoplanin for E. faecalis were used as the positive controls. The plates were kept at room temperature for 20-30 minutes. Then, the plates were placed in the incubator for $18-24$ hours at $35^{\circ} \mathrm{C}$. Following the incubation, the inhibition zones around the discs were evaluated. MIC of the extracts that showed antibacterial activity against test microorganisms was determined. This analysis was performed based on fact that the lowest inhibitory concentration determines the effectiveness on the test microorganisms ( $S$. aureus and C. albicans). In this test, the 12.5, 25, 50, 75 and 100 $\mathrm{mg} \mathrm{mL} \mathrm{mL}^{-1}$ concentrations of extracts were investigated for their inhibitory effects against various microorganisms. 


\section{Total Antioxidant Test}

The antioxidant activity of extracts were determined by DPPH Radical Scavenging Method. This method is based on the reduction of DPPH, a dark violet color compound and the absorbance reduction was measured by Ultraviolet-Visible (UV-Vis) spectrophotometer [11]. The antioxidant activities of the extracts, which were expressed as the activity of capturing free radicals, were determined by the use of DPPH radicals according to the method of Yilmaz, and Türkmen, et al. [12, 13]. DPPH radicals $(0.025 \mathrm{~g} / \mathrm{L})$ prepared in $3.9 \mathrm{~mL}$ methanol was added to $100 \mu \mathrm{L}$ of the extracts. The mixture was incubated at room temperature and in the dark for 30 minutes. In this analysis based on the opening of purple color of the DPPH solution, the residual amount of DPPH was measured at $515 \mathrm{~nm}$ by using spectrophotometer. Inhibition of DPPH was calculated as percent by the following formula. All analyzes were repeated 3 times. For the Control value: Methanol + DPPH, For Blank: Methanol, Against Blank (methanol): Methanol + DPPH (control), Against Blank: Plant sample + DPPH were used. BHT at $200 \mu \mathrm{g} \mathrm{mL} \mathrm{m}^{-1}$ concentration was used as standard antioxidant substance.

Inhibition $\%=[($ Control Absorbance - Sample Absorbance / Control Absorbance) $] \times 100$

\section{Total Flavonoid Content (TFC)}

According to the method reported by Sharma and Vig (2013), $1 \mathrm{~mL}$ of extracts were diluted with $5 \mathrm{~mL}$ of distilled water [14]. $0.3 \mathrm{~mL} \mathrm{NaNO}$ (5\%) was added to the samples and incubated for $5 \mathrm{~min}$ at room temperature. Then, $0.6 \mathrm{~mL}$ of $\mathrm{AlCl}_{3} \cdot 6 \mathrm{H}_{2} \mathrm{O}$ $(10 \%)$ was added to the mixture and after incubation under the same conditions, $2 \mathrm{~mL}$ of $1 \mathrm{M} \mathrm{NaOH}$ was added and the final volume of reaction mixture was completed to $10 \mathrm{~mL}$ with distilled water. The absorbance of the prepared mixtures was determined spectrophotometrically at $510 \mathrm{~nm}$. Routine equivalent standard was used by solving in distilled water at $0-125 \mathrm{mg} / \mathrm{mL}$ concentrations. All analyzes were repeated 3 times and calculated according to the slope value $(\mathrm{y}=10,954 \mathrm{x})$. TFC was expressed as $\mathrm{mg}$ routine equivalents ( $\mathrm{mg} \mathrm{RE} / \mathrm{g}$ ) per gram.

\section{Total Phenolic Content (TPC)}

Soluble phenolic content of fruit and leaf extracts were determined using Folin-Ciocalteu reagent. $0.5 \mathrm{~mL}$ of extracts were incubated in a water bath at $45^{\circ} \mathrm{C}$ for 45 minutes with the addition of $2.5 \mathrm{~mL}$ of Folin-Ciocalteu reagent (10\%) and 2.5 $\mathrm{mL}$ of $\mathrm{NaHCO}_{3}$ (7.5\%). The absorbance of the mixtures was measured spectrophotometrically at $765 \mathrm{~nm}$. According to the calibration graph using gallic acid as standard, the TPC is expressed as mg gallic acid equivalents (mg GAE/g) per gram [15]. Gallic acid standard was used by solving it in distilled water at $0-150 \mu \mathrm{g} / \mathrm{mL}$ concentrations. All analyzes were repeated 3 times and calculated according to the slope value $(y=8,8286 x)$.

\section{Statistical Analysis}

Statistical analysis was performed for antioxidant activity, TFC and TPC results. In order to determine significant differences between the samples, the software SPSS 22.0 for Windows (SPSS Inc., Chicago, IL, USA) was used. Variance analysis (ANOVA) and Tukey multiple comparison tests were performed. Each spectrophotometric analysis was repeated at least three times. $(\mathrm{P}<0.05)$.

\section{RESULTS}

The range of the percentage extraction yield of the leaf and fruit extracts was very extensive: from $4.8 \%$ to $51.65 \%$ (Table I). The highest yield was calculated as $51.65 \%$ and $32.45 \%$ in the methanolic and aqueous fruit extracts. However, the yield of the leaf extracts were lower than that of fruit samples. This value for leaf extracts ranged from $4.8 \%$ to $11.4 \%$. For both fruit and leaf samples, the high yield was observed in methanolic extracts. Negative control (methanol) showed no inhibitory effect on strains. All leaf extracts displayed no antibacterial activity against B. subtilis, S. epidermis, E. coli, Klebsiella spp., E. cloacae and E. faecalis. However, the prepared fruit samples showed no inhibitory effect on tested microorganisms, except on $E$. faecalis. Aqueous fruit extract had bacteriostatic activity on this bacteria (Table IV), (Figure 3). As seen from Table II, leaf aceton, methanol and ethanol extracts had only antibacterial activity against $S$. aureus. The most effective extract on $S$. aureus was ethanolic leaf sample with the $13 \mathrm{~mm}$ zone diameter (Table II; Figure 1). This activity was lower than inhibition diameter of tetracycline positive control $(23 \mathrm{~mm})$. Remarkable antifungal activity of acetone and ethanol leaf extracts was observed on $C$. albicans (Table III; Figure 2). While control of nystatin resulted in $15 \mathrm{~mm}$ against $C$. albicans, the effect of extracts ranged between $10 \mathrm{~mm}$ and $12 \mathrm{~mm}$. MIC analysis was performed for leaf acetone, methanol and ethanol extracts showing antimicrobial activity on S. aureus and C. albicans.

Table I. Percentage yield of leaf and fruit extracts

\begin{tabular}{|ccc|}
\hline Name of Extract & $\begin{array}{c}\text { Amount of leaf and } \\
\text { fruit extracts after } \\
\text { evaporation }(\mathrm{g})\end{array}$ & $\begin{array}{c}\text { Percent yield of leaf } \\
\text { and fruit extracts }(\%)\end{array}$ \\
\hline Leaf-Water & 0.85 & 8.5 \\
\hline Leaf-Methanol & 1.14 & 11.4 \\
\hline Leaf-Ethanol & 0.53 & 5.3 \\
\hline Leaf-Chloroform & 0.53 & 5.3 \\
\hline Leaf-Acetone & 0.48 & 4.8 \\
\hline Fruit-Water & 6.49 & 32.45 \\
\hline Fruit-Methanol & 10.33 & 51.65 \\
\hline Fruit-Ethanol & 5.48 & 27.4 \\
\hline Fruit-Chloroform & 0.68 & 3.4 \\
\hline Fruit-Acetone & 0.97 & 4.85 \\
\hline
\end{tabular}


Table II. Diameter of the inhibition zone $(\mathrm{mm})$ of the leaf extracts $(100 \mathrm{mg} / \mathrm{mL}$ concentration, $20 \mu \mathrm{L})$ against B. subtilis, S. aureus and S. epidermidis Microorganisms tested Leaf-Acetone Leaf-Chloroform Leaf-Methanol Leaf-Ethanol Leaf-Water Methanol (NC) Tetracycline (PC)

$\begin{array}{cccccccc}\text { B. subtilis } & - & - & - & - & - & - & 25 \\ \text { S. aureus } & 11 & - & 10 & 13 & - & - & 23 \\ \text { S. epidermidis } & - & - & - & - & - & - & 14\end{array}$

(-) represents a no inhibition zone against microorganism. PC: Positive control, NC: Negative control

Table III. Diameter of the inhibition zone $(\mathrm{mm})$ of the leaf extracts $(100 \mathrm{mg} / \mathrm{mL}$ concentration, $20 \mu \mathrm{L})$ against C. albicans

\begin{tabular}{|c|c|c|c|c|c|c|}
\hline $\begin{array}{l}\text { Microorganisms } \\
\text { tested }\end{array}$ & Leaf-Acetone & $\begin{array}{l}\text { Leaf - } \\
\text { Chloroform }\end{array}$ & Leaf-Methanol & Leaf-Ethanol & Leaf-Water & Methanol (NC) \\
\hline
\end{tabular}

C. albicans $\quad 10$

10

12

(-) represents a no inhibition zone against microorganism. PC: Positive control, NC: Negative control

Table IV. Diameter of the inhibition zone $(\mathrm{mm})$ of the fruit extracts $(100 \mathrm{mg} / \mathrm{mL}$ concentration, $20 \mu \mathrm{L})$ towards E. faecalis

\begin{tabular}{cccccccc}
$\begin{array}{l}\text { Microorganisms } \\
\text { tested }\end{array}$ & Fruit-Acetone & $\begin{array}{l}\text { Fruit - } \\
\text { Chloroform }\end{array}$ & Fruit-Methanol & Fruit-Ethanol & Fruit-Water & Methanol (NC) & Teicoplanin (PC) \\
\hline E. faecalis & - & - & - & - & 1.8 & - & 19
\end{tabular}

(-) represents a no inhibition zone against microorganism. PC: Positive control, NC: Negative control

Table V. Minimum inhibitory concentration (MIC) values of leaf-acetone, leaf-ethanol and leaf methanol extracts against the S. aureus

\begin{tabular}{|c|c|c|c|c|c|c|c|}
\hline \multirow{6}{*}{ S. aureus } & $\begin{array}{l}\text { Leaf-Acetone } \\
(12.5 \mathrm{mg} / \mathrm{mL})\end{array}$ & $\begin{array}{l}\text { Leaf-Acetone } \\
(25 \mathrm{mg} / \mathrm{mL})\end{array}$ & $\begin{array}{c}\text { Leaf-Acetone } \\
(50 \mathrm{mg} / \mathrm{mL})\end{array}$ & $\begin{array}{c}\text { Leaf-Acetone } \\
(75 \mathrm{mg} / \mathrm{mL})\end{array}$ & $\begin{array}{l}\text { Leaf-Acetone } \\
(100 \mathrm{mg} / \mathrm{mL})\end{array}$ & Methanol (NC) & Tetracycline (PC) \\
\hline & - & - & - & 9 & 11 & - & 24 \\
\hline & $\begin{array}{l}\text { Leaf-Ethanol } \\
(12.5 \mathrm{mg} / \mathrm{mL})\end{array}$ & $\begin{array}{l}\text { Leaf-Ethanol } \\
(25 \mathrm{mg} / \mathrm{mL})\end{array}$ & $\begin{array}{c}\text { Leaf-Ethanol } \\
(50 \mathrm{mg} / \mathrm{mL})\end{array}$ & $\begin{array}{l}\text { Leaf-Ethanol } \\
(75 \mathrm{mg} / \mathrm{mL})\end{array}$ & $\begin{array}{l}\text { Leaf-Ethanol } \\
(100 \mathrm{mg} / \mathrm{mL})\end{array}$ & Methanol (NC) & Tetracycline (PC) \\
\hline & - & 9 & 11 & 13 & 13 & - & 26 \\
\hline & $\begin{array}{c}\text { Leaf-Methanol } \\
(12.5 \mathrm{mg} / \mathrm{mL})\end{array}$ & $\begin{array}{c}\text { Leaf-Methanol } \\
(25 \mathrm{mg} / \mathrm{mL})\end{array}$ & $\begin{array}{l}\text { Leaf-Methanol } \\
(50 \mathrm{mg} / \mathrm{mL})\end{array}$ & $\begin{array}{c}\text { Leaf-Methanol } \\
(75 \mathrm{mg} / \mathrm{mL})\end{array}$ & $\begin{array}{l}\text { Leaf-Methanol } \\
(100 \mathrm{mg} / \mathrm{mL})\end{array}$ & Methanol (NC) & Tetracycline (PC) \\
\hline & - & - & - & 8 & 10 & - & 24 \\
\hline
\end{tabular}

(-) represents a no inhibition zone against microorganism. PC: Positive control, NC: Negative control

Table VI. Minimum inhibitory concentration (MIC) values of leaf-acetone and leaf ethanol extracts against the C. albicans

\begin{tabular}{|c|c|c|c|c|c|c|c|}
\hline \multirow{4}{*}{ C. albicans } & $\begin{array}{l}\text { Leaf-Acetone } \\
\text { (12.5 } \mathrm{mg} / \mathrm{mL})\end{array}$ & $\begin{array}{c}\text { Leaf-Acetone } \\
(25 \mathrm{mg} / \mathrm{mL})\end{array}$ & $\begin{array}{c}\text { Leaf-Acetone } \\
(50 \mathrm{mg} / \mathrm{mL})\end{array}$ & $\begin{array}{l}\text { Leaf-Acetone } \\
(75 \mathrm{mg} / \mathrm{mL})\end{array}$ & $\begin{array}{l}\text { Leaf-Acetone } \\
(100 \mathrm{mg} / \mathrm{mL})\end{array}$ & Methanol (NC) & Nystatin (PC) \\
\hline & - & - & - & 9 & 10 & - & 13 \\
\hline & $\begin{array}{l}\text { Leaf-Ethanol } \\
(12.5 \mathrm{mg} / \mathrm{mL})\end{array}$ & $\begin{array}{c}\text { Leaf-Ethanol } \\
(25 \mathrm{mg} / \mathrm{mL})\end{array}$ & $\begin{array}{l}\text { Leaf-Ethanol } \\
(50 \mathrm{mg} / \mathrm{mL})\end{array}$ & $\begin{array}{l}\text { Leaf-Ethanol } \\
(75 \mathrm{mg} / \mathrm{mL})\end{array}$ & $\begin{array}{l}\text { Leaf-Ethanol } \\
(100 \mathrm{mg} / \mathrm{mL})\end{array}$ & Methanol (NC) & Nystatin (PC) \\
\hline & - & - & 10 & 11 & 12 & - & 13 \\
\hline
\end{tabular}

(-) represents a no inhibition zone against microorganism. PC: Positive control, NC: Negative control

Table VII. Total phenolic content (TPC), Total flavonoid content (TFC) and antioxidant activity (DPPH scavenging) of different leaf extracts of Ficus sycomorus

\begin{tabular}{|c|c|c|c|}
\hline Sample & $\begin{array}{c}\text { TPC } \\
(\text { mg GAE/g) }\end{array}$ & $\begin{array}{c}\text { TFC } \\
\text { (mg RE/g) }\end{array}$ & $\begin{array}{c}\text { DPPH } \\
(\%)\end{array}$ \\
\hline Leaf-water & ${ }^{*} 3.72 \pm 0.08^{\mathrm{b}}$ & ${ }^{\star} 0.19 \pm 0.015^{c}$ & ${ }^{\star} 1 \pm 2.55^{\mathrm{d}}$ \\
\hline Leaf-acetone & ${ }^{\star} 2.55 \pm 0.38^{c}$ & ${ }^{\star} 1.38 \pm 0.306^{\mathrm{a}}$ & $* 33 \pm 3.38^{\mathrm{b}}$ \\
\hline Leaf-chloroform & ${ }^{\star} 7.09 \pm 0.23^{\mathrm{a}}$ & ${ }^{\star} 1.24 \pm 0.064^{\mathrm{ab}}$ & ${ }^{\star} 42 \pm 0.13^{\mathrm{a}}$ \\
\hline Leaf -ethanol & ${ }^{*} 2.23 \pm 0.00^{c}$ & ${ }^{*} 1.37 \pm 0.246^{\mathrm{a}}$ & ${ }^{\star} 18 \pm 0.13^{c}$ \\
\hline Leaf -methanol & ${ }^{\star} 2.38 \pm 0.09^{c}$ & ${ }^{\star} 0.84 \pm 0.107^{\mathrm{b}}$ & ${ }^{\star} 47 \pm 2.17^{\mathrm{a}}$ \\
\hline BHT $\left(200 \mu \mathrm{g} \mathrm{mL}^{-1}\right)$ & & & ${ }^{\star} 26.29 \pm 0.18^{\mathrm{e}}$ \\
\hline
\end{tabular}

Values are mean \pm Standard Deviation (SD) of three replicate analyses. $100 \mathrm{mg} / \mathrm{mL}$ concentration was used for the tests. ${ }^{*}$ (The presented datas are mean of triplicate determinations ( $n=3), \pm$ Standard Deviation. The difference between the values expressed by the different symbols in table $(a-c$, and a-e) is significant $(P<0.05))$. BHT: Butylated hydroxytoluene 
Table VIII. Total phenolic content (TPC), Total flavonoid content (TFC) and antioxidant activity (DPPH scavenging) of the different fruit extracts of Ficus sycomorus

\begin{tabular}{|c|c|c|c|}
\hline Sample & $\begin{array}{l}\text { TPC } \\
\text { (mg GAE/g) }\end{array}$ & $\begin{array}{l}\text { TFC } \\
\text { (mg RE/g) }\end{array}$ & DPPH (\%) \\
\hline Fruit-water & $\star 5.62 \pm 0.05^{c}$ & ${ }^{\star} 0.07 \pm 0.004^{\mathrm{d}}$ & ${ }^{*} 76 \pm 2.23^{b}$ \\
\hline Fruit-acetone & ${ }^{\star} 11.29 \pm 0.39^{\mathrm{a}}$ & ${ }^{\star} 1.38 \pm 0.021^{\mathrm{a}}$ & ${ }^{\star} 86 \pm 0.06^{\mathrm{a}}$ \\
\hline Fruit-chloroform & ${ }^{\star} 7.78 \pm 0.33^{b}$ & ${ }^{\star} 1.08 \pm 0.058^{b}$ & ${ }^{*} 69 \pm 1.21^{c}$ \\
\hline Fruit-ethanol & ${ }^{\star} 1.93 \pm 0.27^{\mathrm{d}}$ & ${ }^{\star} 0.32 \pm 0.009^{c}$ & ${ }^{*} 86 \pm 4.78^{\mathrm{a}}$ \\
\hline Fruit-methanol & ${ }^{\star} 1.91 \pm 0.33^{\mathrm{d}}$ & ${ }^{\star} 0.12 \pm 0.013^{\mathrm{d}}$ & ${ }^{\star} 86 \pm 0.19^{\mathrm{a}}$ \\
\hline
\end{tabular}

Values are mean \pm Standard Deviation (SD) of three replicate analysis. $100 \mathrm{mg} / \mathrm{mL}$ concentration was used for the tests. ${ }^{*}($ The presented datas are mean of triplicate determinations ( $n=3)$, \pm Standard Deviation. The difference between the values expressed by the different symbols in table $(a-d$ and $a-c)$ is significant $(P<0.05))$.

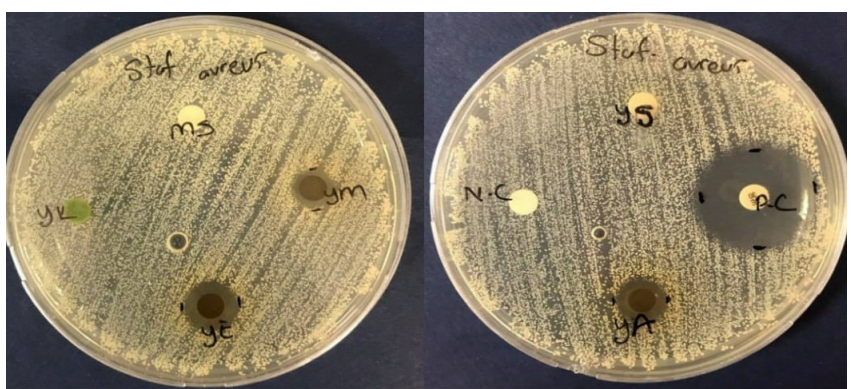

Figure 1. Inhibition zone of leaf-acetone (YA), leaf-methanol (YM) and leaf-ethanol (YE) extracts against $S$. aureus

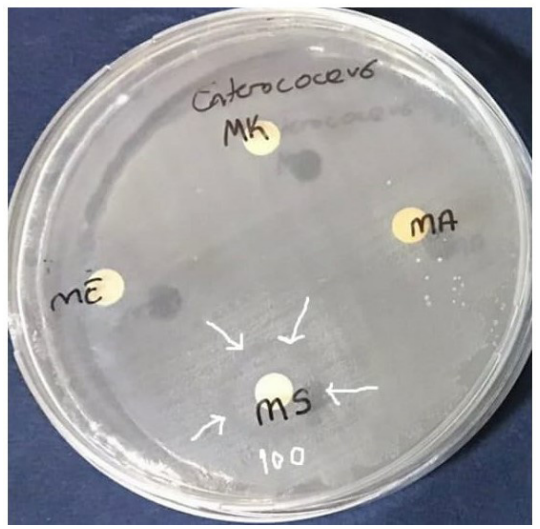

Figure 3. Bacteriostatic activity of fruit-pure water (MS) extract towards E. faecalis, no inhibition zone of other fruit and leaf extracts

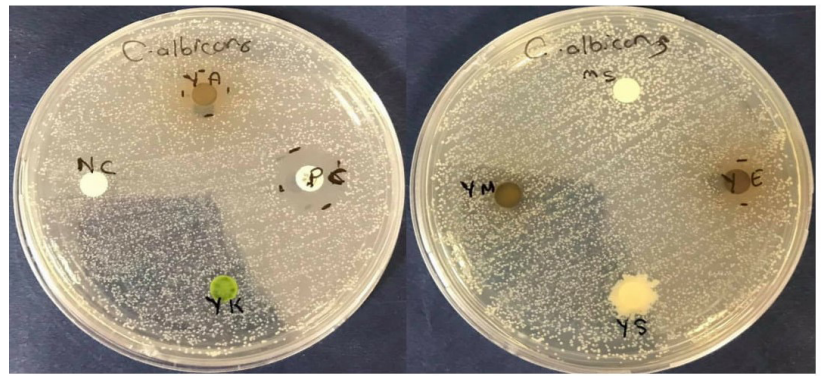

Figure 2. Inhibition zone of leaf-acetone (YA) and leaf-ethanol (YE) extracts towards C. albicans

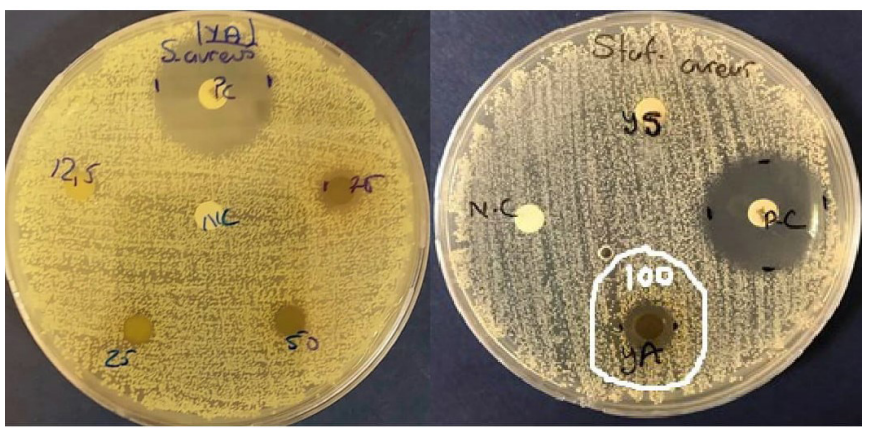

Figure 4. The inhibition zone towards S. aureus at different concentration of the leaf-acetone extracts (YA) 


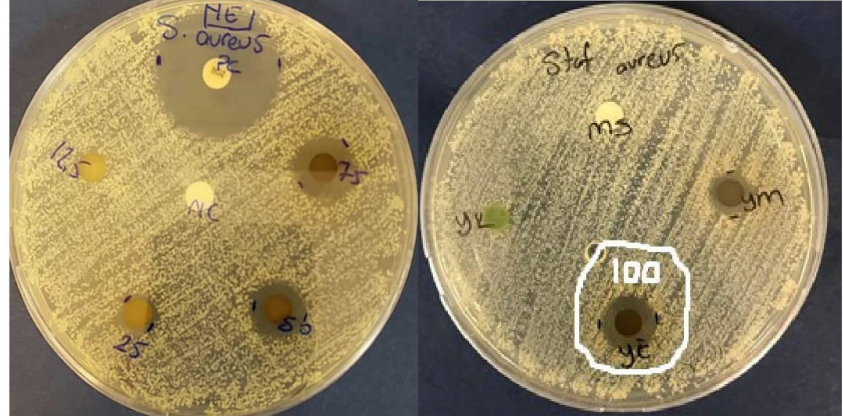

Figure 5. The inhibition zone towards S. aureus at different concentration of the leaf-ethanol extracts (YE)

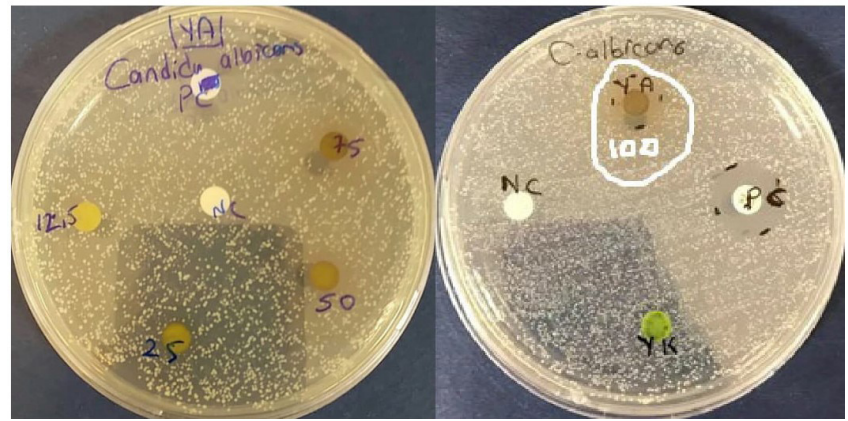

Figure 7. The inhibition zone towards C. albicans at different concentration of the leaf-acetone extracts (YA)

Minimum inhibitory concentration value for leaf acetone was observed starting at $75 \mathrm{mg} / \mathrm{mL}$ concentration against $S$. aureus and C. albicans (Table V-VI; Figure 4, 7). MIC values of ethanolic and methanolic leaf extracts were 25 and $75 \mathrm{mg} / \mathrm{mL}$ on $S$. aureus (Table V; Figure 5, 6). MIC value $(50 \mathrm{mg} / \mathrm{mL})$ of ethanolic leaf extract observed against $C$. albicans was lower than that of acetone sample (Table VI; Figure 8).

In this present study, all quantitative examination of phytochemical analysis and DPPH were found statistically significant $(\mathrm{P}<0.05)$. As can be seen in Table VII-VIII, TPC and TFC of the extracts ranged from $1.91 \pm 0.33$ to $11.29 \pm 0.39 \mathrm{mg}$ GAE/g; from $0.07 \pm 0.004$ to $1.38 \pm 0.306 \mathrm{mg} \mathrm{RE} / \mathrm{g}$, respectively. High TPC value was calculated as $11.29 \pm 0.39 \mathrm{mg}$ GAE/g in the acetone fruit extract. However, the lower TPC values ranging from $1.93 \pm 0.27$ to $1.91 \pm 0.33 \mathrm{mg}$ GAE$/ g$ were obtained from ethanolic and methanolic extracts. Highest TFC was identified in acetone leaf and fruit extracts, $1.38 \pm 0.306$ and $1.38 \pm 0.021 \mathrm{mg}$ $\mathrm{RE} / \mathrm{g}$. The TFC was noted as minimum in aqueous fruit extract $(0.07 \pm 0.004)$. In leaf extracts, chloroform extract was the highest TPC value (7.09 \pm 0.23$)$. Chloroform has the least polarity index in the test solvent used but which yielded the highest phenolic substances. This may be due to the high hydrophobicity of the compounds. The results of flavonoids for all leaf samples were lower than the results of phenolic substances. This is because flavonoids are the subgroup of phenolics.

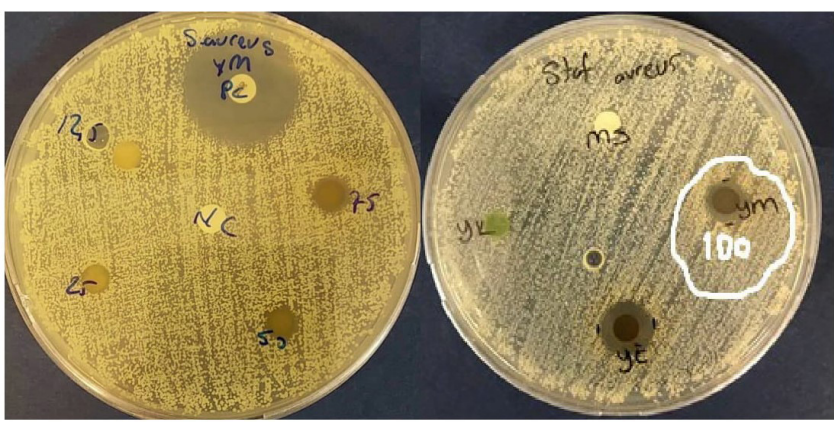

Figure 6. The inhibition zone towards S. aureus at different concentration of the leaf-methanol extracts (YM)

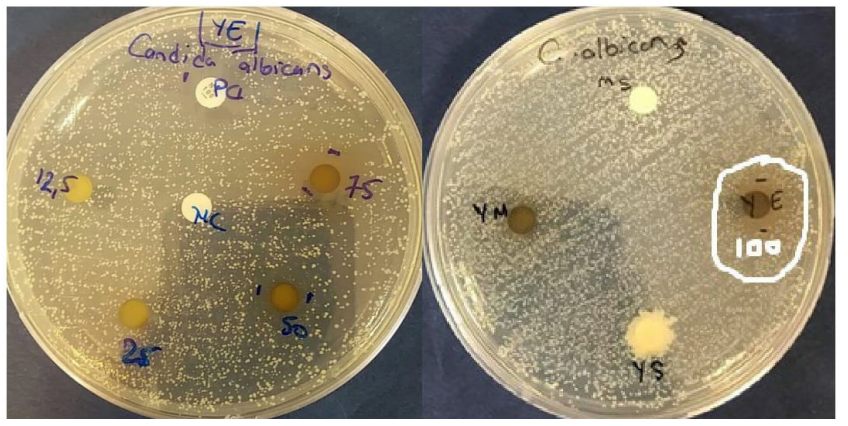

Figure 8. The inhibition zone towards C. albicans at different concentration of the leaf-ethanol extracts (YE)

2,2-diphenyl-1-picrylhydrazyl radical scavenging activity was evaluated by comparing it with the standard antioxidant activity of BHT. The DPPH activity of F. sycomorus samples was not comparable with that of BHT testing at $200 \mu \mathrm{g} \mathrm{mL}-1$ concentration. The antioxidant activity of DPPH was observed in the leaf extracts ranging from $1 \pm 2.55 \%$ to $47 \pm 2.17 \%$. TPC and TFC values of leaf methanolic extract showed the highest antioxidant activity $(47 \pm 2.17 \%)$ but still they were lower than the values of chloroform and acetone extracts that had the maximum contents. Even though the low DPPH activity $(1 \pm 2.55 \%)$, aqueous leaf extract had the high TPC content $(3.72 \pm 0.08)$. The free radical scavenging capacity of fruit extracts was higher than that of the leaf extracts. Based on the polarity of solvents, the highest antioxidant activity of DPPH for fruit samples was recorded as $86 \%$ in methanol, ethanol and acetone extracts. According to Table VII-VIII, inhibition \% values ranged from $1 \pm 2.55 \%$ to $86 \pm 0.06$. According to these results, the presence of antioxidant compounds of fruit and leaf extracts could be effective against the negative effects of free radicals. Our results also indicated the effect of extraction solvents on antioxidant activity and phytochemical contents in bioactivity studies of plants. 


\section{DISCUSSION}

Four Gram-positive, three Gram-negative bacterial strains and one fungal strain were tested for antimicrobial activity of the extracts. Extracts did not show any inhibitory activity against three Gram-negative bacterial strains. However, a moderate activity was observed against one of the four Grampositive bacterial strains, $S$. aureus and one fungal strain (Table II-III). The inhibition zone to $S$. aureus and $C$. albicans at concentrations of $25,50,75,100 \mathrm{mg} / \mathrm{mL}$ and 50, 75, $100 \mathrm{mg} /$ $\mathrm{mL}$ of leaf extract was in the range of $8-13 \mathrm{~mm}$ and $9-12 \mathrm{~mm}$, respectively (Table V-VI). The antimicrobial activity of fruits and leaves of F. sycomorus extracts differentiated according to the species of microorganisms tested, the solvents used and extraction process.

Ghareeb et al., reported leaf-methanol extract of F. sycomorus which showed antimicrobial activity against E.coli $(14 \mathrm{~mm})$, S. aureus $(27 \mathrm{~mm})$ and $C$. albicans $(16 \mathrm{~mm})$ but no antifungal activity to $A$. niger [16]. In addition, the methanolic and ethanolic leaf extracts showed inhibitory effect on test microorganism, $S$. aureus. [17]. Similar results were reported by Saleh and Al - Mariri (2017), who recorded that the acetone leaf extract of F. sycomorus showed good antibacterial activity against Listeria monocytogenes, S. aureus, Bacillus cereus, Escherichia coli O:157, Salmonella typhimurium, Brucella melitensis, Proteus mirabilis, Yersinia enterocolitica O:9, Pseudomonas aeruginosa and Klebsiella pneumonia [18]. This antibacterial activity on $S$. aureus $(9 \mathrm{~mm})$ was lower than the inhibition diameter of our leaf acetone extract $(11 \mathrm{~mm})$. However, in Braide et al's study no inhibition zone against E.coli, Klebsiella spp., S. aureus and $P$. aeruginosa was observed in the leaf-methanolic extract [8].

In this study, inhibition against C. albicans and S. aureus at 100 $\mathrm{mg} / \mathrm{mL}$ was observed. $S$. aureus causes superficial skin lesions (boils, shallots), localized abscesses, deep-seated infections, severe skin infections (furunculosis), infection of hospitalacquired surgical wounds and food poisoning. C. albicans causes fungal urinary tract infections (UTI), genital fungal infections, fungal skin infections and oral thrush. The susceptibility of $C$. albicans and S. aureus to leaf extracts of F. sycomorus was shown to be effective against diseases caused by these organisms and can be used as a healing agent.

In the study of Saleh et al., the MIC was evaluated by microdilution broth method to establish the susceptibility of pathogens to the acetone-leaf extract [9]. These values were found $7.3 \mathrm{mg} / \mathrm{mL}$ for resistant S.aureus and $6.6 \mathrm{mg} / \mathrm{mL}$ for sensitive $S$. aureus. In another study of Saleh and Al-Mariri, the MIC value of leafacetone extract against $S$. aureus was $130.2 \mathrm{mg} / \mathrm{mL}$ [18]. This value was rather higher than that of our acetone extract value (75 mg/mL.). Similar to our results, Jouda et al., showed that the MIC value was $25 \mathrm{mg} / \mathrm{mL}$ for leaf-ethanol extract against $S$. aureus [17]. Also, MIC value of leaf-methanolic extract against S. aureus was determined as $6.25-3.125$ and $8.7-9.2 \mathrm{mg} / \mathrm{mL}$ in Saleh et al., and Jouda et al., studies which was lower than that of ours $[9,17]$.

The antioxidant activity and phytochemical properties of the $F$. sycomorus extracts were solvent dependent. In our study the total content of phenolic and flavonoid compounds varied in different fractions based on polarities of solvents ranging from $1.91 \pm 0.33$ to $11.29 \pm 0.39 \mathrm{mg} \mathrm{GAE} / \mathrm{g} ; 0.07 \pm 0.004$ to $1.38 \pm 0.021 \mathrm{mg} \mathrm{RE} / \mathrm{g}$ (Table VII-VIII). The fruit extracts exhibited the highest DPPH removal activity followed by chloroform $(69 \pm 1.21 \%)$, water $(76 \pm 2.23 \%)$, acetone, ethanol and methanol (86 $\pm 0.06-4.78 \%)$ (Table VII-VIII). This indicated that antioxidant activity was solvent - independent but was strongly dependent on the fruit samples taken from the F. sycomorus. The fruit extracts of $F$. sycomorus showed stronger antioxidant capacity as compared to leaf extracts.

Similarly, Al-matani et al., reported that the extractive yields of the F. sycomorus fruit varied depending on the polarity of solvents used [1]. The highest amount of total extractable compound was in the hexane extract $(18.8 \%)$. This value was rather lower than that of our methanol extract (51.65\%). Whereas, $11.09 \%$ and $4.06 \%$ the total extractable content value of methanolic and aqueous F.sycomorus leaf extracts reported by El Sayed et al., was higher than the values of this study [20].

Al-matani et al., predicated that TPC values of F. sycomorus fruit extracts were in the range of $3.43 \pm 2.16$ and $81.56 \pm 0.43 \mathrm{mg}$ GAE/100 g [1]. These were quite lower than the TPC values of F. sycomorus fruit extract calculated per g. El Sayed et al., noted as $124.00 \pm 4.96$ and $26.31 \pm 3.76 \mathrm{mg} \mathrm{GAE} / \mathrm{g}$ of the TPC of leaf methanol and water extract, which was dramatically higher than our results [20]. Moreover, we found out that in El-Beltagi et al's study., TFC values of $F$. sycomorus extracts $(2.48 \pm 0.16$ and $12.58 \pm 0.01 \mathrm{mg} Q \mathrm{QE} / \mathrm{g})$ were much higher than our results [19].

This study supported previous reports by Samuel et al., and El Sayed et al. on the DPPH radical scavenging activity of F. sycomorus fruit and leaf extract prepared by different solvents $[20,21]$. In our study, the ethanolic extract of F. sycomorus fruit gave the high antioxidant activity $(86 \pm 4.78 \%)$ as compared with the values reported (72.471\%) by El-Beltagi et al. [19]. Antioxidant results of our study were in accordance with the results of Abdel-Aty et al., who found the highest value of DPPH radical scaveging activity (above $75 \%$ ) in F. sycomorus latex extract [22].

In conclusion, F. sycomorus may be used as an alternative to antibiotics that are resistant to pathogenic microorganisms. In this study, leaf extracts were found to be more effective than fruit extracts against gram-positive $S$. aureus bacteria. It can also be used as medicine or food against infections caused by various bacteria or fungi. Fruits and leaves of F. sycomorus can be consumed as antioxidants against free radicals formed in the human body.

In the light of our findings, we think that in-vivo and in-vitro antioxidant mutagenic toxicity tests can guide the future studies on the effect of eukaryotic cells.

\section{Acknowledgement}

The authors would like to thank Near East University and Hospital, Kilis 7 Aralık University. 


\section{Compliance with Ethical Standards}

Authors' Contributions: Concept - M.S.O., F.T.; Design M.S.O., F.T., H.A.M.T.; Supervision - M.S.O.; Resource - M.S.O., K.S., E.G., H.A.M.T; Materials - M.S.O., K.S., E.G., H.A.M.T; Data collection and/or Processing -M.S.O., F.T., E.G.; Analysis and/or interpretation - M.S.O., F.T., K.S., H.A.M.T.; Literature search - M.S.O., F.T.; Writing - M.S.O., F.T., H.A.M.T; Critical Reviews - M.S.O., K.S., H.A.M.T.

Conflict of Interest: The authors have no conflict of interest to declare.

Financial Disclosure: The authors declared that this study has received no financial support.

\section{REFERENCES}

[1] Al-Matani SK, Al-Wahaibi RNS, Hossain MA. In vitro evaluation of the total phenolic and flavonoid contents and the antimicrobial and cytotoxicity activities of crude fruit extracts with different polarities from Ficus sycomorus. Pac Sci Review A: Natural Sci Eng 2015; 17: 103-8. http://dx.doi. org/10.1016/j.psra.2016.02.002.

[2] Hossain MA. A review on Ficus sycomorus: A potential indigenous medicinal plant in Oman. J King Saud Univ Sci 2018;30: 293-424. https://doi.org/10.1016/j.jksus.2018.07.002.

[3] Bulut A. Cümbez' e yazık ediyoruz. Kıbrıs Gazetesi 2018; August 27. Retrieved from https://www.kibrisgazetesi.com

[4] Kuzey Kıbrıs Türk Cumhuriyeti Turizm ve Çevre Bakanlığı. North Cyprus 2016. Retrieved from http:// myislandnorthcyprus.com/ne-yapilir/lala-pasa-camisi-stnicholas-katedrali

[5] Ahmad AS, Dahiru A, Muhammad AT, Idris H, Gautam K. Phytochemical screening and antimicrobial activity of Ficus sycomorus extracts of the stem bark and leaves on some pathogenic microorganisms. American Chem Sci J 2016; 13 : 1-5. doi: 10.9734/ACSJ/2016/23654.

[6] Dluya T, Daniel D, Gaiuson Y. Comparative biochemical evaluation of leaf extracts of Ficus sycomorus and Piliostigma thonningii plant. J Med Plants Studies 2015; 3: 32-7.

[7] Kasnak C, Palamutoğlu R. Doğal antioksidanların sınıflandırılması ve insan sağlığına etkileri. Gıda Bilim ve Teknoloji Dergisi 2015; 3: 226-34. doi: 10.24925/turjaf.v3i5.226-234.17.

[8] Braide W, Dokubo KO, Adeleye SA, Uzoh CV, Akobundu CI. Phytochemical properties, toxicological screening and antibacterial qualities of various parts extracts of Ficus sycomorus. J Med Plant Herbal Ther Res 2018; 6: 1-8.

[9] Saleh B, Hammoud R, Al-Mariri A. Antimicrobial activity of Ficus sycomorus L. (Moraceae) leaf and stem-bark extracts against multidrug resistant human pathogens. Herba Pol 2015; 61: 39-49. doi: 10.1515/hepo-2015-0009.
[10] Bauer AW, Kirby WMM, Sherris JC, Turck M. Antibiotic susceptibility testing by a standardized single disk method. American J Clin Pathol 1966; 45: 493-6.

[11] Büyüktuncel E. Toplam fenolik içerik ve antioksidan kapasite tayininde kullanılan başlıca spektrofotometrik yöntemler. Marmara Pharm J 2013; 17: 93-103. doi: 10.12991/201317377.

[12] Yllmaz OM. Determination of antioxidant activity and phenolic acid composition of main wheat varieties grown in Turkey and enrichment of bread with pomegranate husk extract. PhD Thesis, Ankara University 2011; Ankara, Turkey.

[13] Turkmen UF, Takcı MHA, Sekeroglu N. Total phenolic content, antioxidant and antimicrobial activities of homemade and industrial samples of breakfast zahter, herbal mixture. Akademik Gıda 2016; 14: 242-6.

[14] Sharma S, Vig AP. Evaluation of in vitro antioxidant properties of methanol and aqueous extracts of Parkinsonia aculeata L. leaves. The Scientific World J 2013; 1: 2-7. doi: $10.1155 / 2013 / 604865$.

[15] Stanković MS. Total phenolic content, flavonoid concentration and antioxidant activity of Marrubium peregrinum l. extracts. Kragujevac J Sci 2011; 33: 63-72.

[16] Ghareeb MA, Refahy LA, Saad AM, Osman NS, AbdelAziz MS, ElShazly MA, Mohamed AS. In vitro antimicrobial activity of five Egyptian plant species. J Applied Pharm Sci 2015; 5: 045-049. doi: 10.7324/JAPS.2015.58.S7.

[17] Jouda MM, Elbashiti T, Masad A, Dardona Z. Synergistic effect of Ficus sycomorus (Moraceae) leaf and stem-bark extracts against some selected pathogens. Int J Sci Res Publications 2015; 5: 492-6.

[18] Saleh B, Al-Mariri A. Phytochemical constitutes of Ficus sycomorus $L$. and inhibitory effect of their crude extracts against bacterial pathogens. J Natural Products 2017; 10: 06-14.

[19] El-Beltagi HS, Mohamed HI, Abdelazeem AS, Youssef R, Safwat G. GC-MS analysis, antioxidant, antimicrobial and anticancer activities of extracts from Ficus sycomorus fruits and leaves. Not Bot Horti Agrobo 2019; 47: 493-505. doi:10.15835/nbha47211405.

[20] El-Sayed MM, El-Hashash MM, El-Wakil EA, Ghareeb MA. Total phenolic contents and antioxidant activities of Ficus sycomorus and Azadirachta indica. Pharmacologyonline 2009; 3: 590-602.

[21] Samuel YT, Hayatu IG, Olufunke AS, Hamza HM. Antioxidant and phytochemical screening of ethanol extracts of Ficus sycomorus (moraceae) leaves and Faidherbia albida (fabaceae) stem-bark. Nigerian J Pharm Biomedical Res 2017; 2: 41-5.

[22] Abdel-Aty AM, Ahmed MB, Salama WH, Ali MM, Fahmy AS, Mohamed AS. Ficus carica, Ficus sycomorus and Euphorbia tirucalli latex extracts. Phytochemical screening, antioxidant and cytotoxic properties. Biocatal Agric Biotechnol 2019; 20: 101199. https://doi.org/10.1016/j.bcab.2019.101199. 